\title{
Priority Number
}

National Cancer Institute

\section{Source}

National Cancer Institute. Priority Number. NCI Thesaurus. Code C70763.

An integer designating the relative priority of events, activities, or entities of a similar type. Lower priority number signifies higher priority value. 